\title{
Challenges and Issues in Nursing Leadership
}

\section{Vilma Zydziunaite*}

Professor, Center for Quality and Innovations, Vytautas Magnus University, Kaunas, Lithuania

Welcome to the special edition of the Journal of Nursing \& Care, which attempts to raise challenges and issues in nursing leadership through nursing and care practices within variety of contexts, situations that meet nurses through practicing leadership activities autonomously, in groups or teams in different types of health care organizations, with different consumers/patients and collaborators and by performing different roles such as clinical nurse, nurse practitioner, chief/head nurse, nurse manager or other. Also this issue of the Journal of Nursing $\&$ Care is concerned about research issues in nursing leadership such as research methodologies, methods, concepts, strategies, philosophies and etc.

In today's ever-changing health care environment, nurses require leadership, which provides direction for a new generation of nurses [1]. The past, present and future leadership setting, role of authority, power and influence in leadership, components of the arch of leadership and solutions to effective leadership in a future dimension is all domains that motivate future nurse leaders [2]. Then gaining knowledge to become an effective nurse leader is one way to ensure quality health care for the future [1].

Leadership can be defined as a multifaceted process of identifying a goal or target, motivating other people to act, and providing support and motivation to achieve mutually negotiated goals $[3,4]$. Often the definitions of the words leader and manager are not rare confused. Traditional managers have assigned roles and titles within an organization, as they carry out specific functions, duties and responsibilities. Leaders do not necessarily have any delegated authority. They function within a variety of formal and informal roles [5]. An individual can be a great leader but not a manager. Conversely, an individual can be a manager but not possess many leadership skills [6]. Thus the nursing leadership does not rest merely with administrators and high-level managers, but also can be developed and implemented at the bedside [7].

Nurses are likely to engage in a range of leadership activities in their daily routine. Some will naturally adopt an effective leadership style, while others may find the concept of leadership or seeing themselves as leaders difficult to understand. Effective leadership is critical in delivering high-quality care, ensuring patient safety and facilitating positive staff development [8]. Within the nursing and care practices, anyone who is looked to as an authority (e.g., a nurse taking care of a patient) or who is responsible for giving assistance to others is considered a leader [1] and the nurses leaders, according to Bondas [9] and Roskoski [10], are driving forces and vital to good patient care. This argument is related to Frankel [8] affirmation that dynamic clinical leaders and supportive clinical environments are essential in the development and achievement of best practice models. What means that nurses leaders act within various organizational environments that could motivate or not, the nurse leaders to seek for the best health care as well as nursing quality for their patients, society and nursing profession.

Wisniewski [5] characterizes the nurse leaders as creative and innovative; utilizing their personal influence to empower others and challenging the status quo; they are life-long learners, empathetic, advocates who speak on behalf of their patients, decisive, extraordinary, resilient, supportive, heroic, and intuitive and purpose driven. Then these arguments show the importance of cultivating new nursing leaders is imperative for a healthful society, to the best evidence-based nursing practice as well as to the need to train the nurses for leadership. In this context Valentine [7] notes that we need nursing leadership to exert that influence and by nurturing both leadership as well as clinical skills, we can. Also she raises the issue that the nursing profession trains new nurses on operating the latest technology and complex medical equipment. In contrast, once at the bedside they rarely get the opportunity to apply even basic leadership principles. Nursing as a profession does a disservice to new nurses by not developing their leadership capabilities. Nursing has a responsibility to encourage and support new members of the profession, as they become competent clinicians. Nursing must also make them competent leaders.

Nursing practice needs evidences that are proved by research outcomes. Integration of research evidence into clinical nursing practice is essential for the delivery of high-quality nursing care. Leadership behaviors of nurses, especially, managers and administrators have been identified as important to support research use and evidencebased practice. Yet minimal evidence exists indicating what constitutes effective nursing leadership for this purpose or what kinds of interventions help leaders to successfully influence research-based care [11].

Research on nursing leadership has started in sixth decade of 20 century [12] and till nowadays is still topical phenomenon, which is still under practical and research developments. Besides the practical issues from the research standpoint here exist a lot of research phenomenons within the nursing leadership, e.g., culturally competent care as characteristic of nursing [13]; mentorship, as a competence of nurse leaders [14]; reflective practice, as a premise for effective nursing leadership [15]; relationships between health policy and nursing practice through nursing leadership [16]; the attributes of effective clinical nurse leaders [17]; quality of care provision for elderly through nursing leadership [18]; building of the capacity for evidence-based nursing leadership through executive co-coaching and group clinical supervision [19]; leading the multigenerational nursing workforce [20]; interrelationships between organizational characteristics, job satisfaction and stress, emotional exhaustion and nursing leadership [21, 22]; relationship between nursing leadership and patient outcomes [23]; situational factors and role models in nursing leadership [9]; leadership skills [1]; leadership styles [24-26]; leadership ethics [27]; ethical dilemmas by decision-making within nursing leadership [28] and etc. Also researchers discuss about challenging methodological issues in nursing leadership research issues, for example, application of grounded theory [29]; historical methodology [30] and Q-Methodology

*Corresponding author: Vilma Zydziunaite, Professor, Center for Quality and Innovations, Vytautas Magnus University, Kaunas, Lithuania, E-mail: vilma.vilma@ymail.com

Received May 21, 2012; Accepted May 23, 2012; Published May 25, 2012

Citation: Zydziunaite V (2012) Challenges and Issues in Nursing Leadership. J Nurs Care 1:e105. doi:10.4172/2167-1168.1000e105

Copyright: @ 2012 Zydziunaite V. This is an open-access article distributed under the terms of the Creative Commons Attribution License, which permits unrestricted use, distribution, and reproduction in any medium, provided the original author and source are credited. 
[31] in nursing leadership research; qualitative research in nursing leadership [32] and etc. And the list of research issues within nursing leadership could be continued.

If you would like to contribute to the debates, present articles I the field of challenges and issues in nursing leadership, please do not hesitate to send it to the Journal of Nursing \& Care.

\section{References}

1. Mahoney J (2001) Leadership Skills for the 21st Century. J Nurs Manag 9: 269-271.

2. Jooste K (2004) Leadership: a new perspective. J Nurs Manag 12: 217-223.

3. Porter-O'Grady T (2003) A Different Age for Leadership, Part 1: New Context, New Content. J Nurs Adm 33: 105-110.

4. Porter-O'Grady T (2003b) A Different Age for Leadership, Part 2: New Rules, New Roles. J Nurs Adm 33: 173-178.

5. Wisniewski L (2012) All Nurses Are Leaders

6. Anderson LL (2012) Nurse Leadership versus Management.

7. Valentine SO (2012) Nursing Leadership and The New Nurse. Charlotte, University of North Carolina.

8. Frankel A (2008) What Leadership Styles Should Senior Nurses Develop? Nursing Times 104: 23-24.

9. Bondas T (2006) Paths to Nursing Leadership. J Nurs Manag 14: 332-339.

10. Roskoski J (2012) What is Nursing Leadership?

11. Gifford W, Davies B, Edwards N, Griffin P, Lybanon V, et al. (2007) Managerial leadership for nurses' use of research evidence: an integrative review of the literature. Worldviews Evid Based Nurs 4: 126-145.

12. Bass BM, Bass R (2008) The Bass Handbook of Leadership- Theory, Research and Managerial Applications. Free Press, New York.

13. Aboul Enein F (2005) Facing the Future: Elder Care in Saudi Arabia. Reflect Nurs Leadersh 31: 24-26.

14. Daniels M (2004) Mentoring: Link to the Future. Reflect Nurs Leadersh 30: 24-25.

15. Freshwater D (2004) Tool for Developing Clinical Leadership. Reflect Nurs Leadersh 30: 20-22.

16. Antrobus S, Kitson A (1999) Nursing leadership: influencing and shaping health policy and nursing practice. J Adv Nurs 29: 746-753.

17. Cook M J (2001) The attributes of effective clinical nurse leaders. Nurs Stand 15: 33-36.

18. Dwyer D (2011) Experiences of registered nurses as managers and leaders in residential aged care facilities: a systematic review. Int J Evid Based Healthc 9: $388-402$.

19. Alleyne J, Jumaa MO (2007) Building the capacity for evidence-based clinical nursing leadership: the role of executive co-coaching and group clinical supervision for quality patient services. J Nurs Manag 15: 230-243.

20. Sherman RO (2006) Leading a Multigenerational Nursing Workforce: Issues, Challenges and Strategies. Online J Issues Nurs 11: 3.

21. Stordeur S, D'Hoore W, Vandenberghe Ch (2001) Leadership, organizational stress, and emotional exhaustion among hospital nursing staff. J Adv Nurs 35 : 533-542.

22. Upenieks VV (2003) The Interrelationship of Organizational Characteristics of Magnet Hospitals, Nursing Leadership, and Nursing Job Satisfaction. Health Care Manag (Frederick) 22: 83-98.

23. Wong CA, Cummings GG (2007) The relationship between nursing leadership and patient outcomes: a systematic review. J Nurs Manag 15: 508-521.

24. Morrison RS, Jones L, Fuller B (1997) The Relation Between Leadership Style and Empowerment on Job Satisfaction of Nurses. J Nurs Adm 27: 27-34.

25. Stordeur S, Vandenberghe Ch, D'hoore W (2000) Leadership Styles Across Hierarchical Levels in Nursing Departments. Nurs Res 49: 37-43.
26. Thyer GL (2003) Dare to be different: transformational leadership may hold the key to reducing the nursing shortage. J Nurs Manag11: 73-79.

27. Ciulla JB (2004) Ethics, the Heart of Leadership.(2nd edn) Greewood Publishng Group, Westport.

28. Zydziunaite V, Suominen T, Åsted-Kurki P, Lepaite D (2010) The ethica dilemmas concerning decision-making within health care leadership: systematic literature review. Medicina 46: 595-603.

29. Parry KW (1998) Grounded theory and social process: A new direction for leadership research. The Leadership Quarterly 9: 85-105.

30. Lusk B (1997) Historical Methodology for Nursing Research. Image J Nurs Sch 29: $355-360$.

31. Akhtar-Danesh N, Baumann A, Cordingley L (2008) Q-Methodology in Nursing Research. A Promising Method for the Study of Subjectivity. West J Nurs Res 30: 759-773.

32. Bryman A (2004) Qualitative research on leadership: A critical but appreciative review. The Leadership Quarterly 15: 729-769. 